\title{
Financial Institutions Micro Loans: A Strategy for Reducing Poverty in Nigeria
}

\section{Mufutau Akanmu Popoola}

PhD Candidate, Department of Business and Entrepreneurship, School of Business and Governance, Kwara state university, Malete Nigeria

\begin{abstract}
Aminu Nassir Brimah
Dr., Senior lecturer in Department of Business and Entrepreneurship, School of Business and Governance, Kwara State University, Malete Nigeria.
\end{abstract}

Rotimi Ayodele Gbadeyan

Professor, Department of Marketing, University of Ilorin, Nigeria

\begin{abstract}
This article summarizes the arguments and counter-arguments in the scientific debate on the use of microcredit by financial institutions as a strategic direction for poverty reduction in Nigeria. This study is aimed at studying the impact of microcredit operations provided by commercial banks to business entities, poverty indicators of the country. Five commercial and five microfinance banks of the state of Nigeria were selected as the object of the study. Methodological support of this work includes a survey method (for accumulating primary information on obtaining correct data of respondents on the dynamics of poverty indicators, reducing unemployment, training, skills, expanding income opportunities, etc.). The article presents the results of empirical analysis, showed a significant impact of microcredit processes of financial institutions to reduce poverty indicators in Nigeria. The author notes the need for banks in Nigeria to introduce less aggressive mechanisms for profit, that is, formed on a socialist basis. Based on the results of the study, the author proposed the following recommendations: financial and institutional promotion of major microfinance banks in Nigeria; the increase in government spending on the organization of seminars to prepare and expand business opportunities for community representatives to establish their own business, simplification of mechanisms for the provision of microcredit (on the principles of gender sensitivity, in particular for women entrepreneurs) and reduction of interest rates for entrepreneurs, which will improve both the indicators of financial and economic development of the country, and will contribute to the wellbeing of society as a whole.
\end{abstract}

Keywords: financial institutions, microfinance banks, microcredit, poverty reduction.

JEL Classification: J16, G21, G12.

Cite as: Popoola, M. Ak., Brimah, Am. N., Gbadeyan, A. R. (2019). Financial Institutions Micro Loans: A Strategy for Reducing Poverty in Nigeria). Financial Markets, Institutions and Risks, 3(3), 13-18. http://doi.org/10.21272/fmir.3(3). 13-17.2019.

(C) The Authors, 2019. This article is published with open access at Sumy State University.

\section{Introduction}

Micro loans are a soft loan receive by Small and medium scale enterprises to boost their business. This micro loan can be obtained from commercial banking Nigeria with little interest. Most of the Small-scale businesses in Nigeria cannot do without this soft loan. Popoola,(2014) explained that microfinance is very crucial to economic growth and development,and micro loans is a small amount of money lend to an entrepreneurs to boost their enterprises (Anyakoha,2006;Baumol 2012 \& Ebiringa 2012).Poverty in Nigeria this days is skyrocketed.Adewole et al.,(2018) explain that poverty is a state of being poor by individual who cannot cater for his basic needs. Many people are living in abject poverty, many businesses have been folding up due to economic recession we found ourselves. With the help of financial institutions 
that lending soft loan to Micro and small business operators, this reduce poverty among the populace. (Popoola,2018), Muogbo (2013) and Ruduan (2009).

The besic objective of micro loans to entrepreneurs is to help him/her mobilize fund and using such fund to boost their business activities. Adewole et al., (2018) and Baumol (1981) explained that micro loans are very germane to economic development and poverty reduction. Without adequate financing, there can be no growth or maintance of stable output (Bequer,2002 \& Coulter,2001) also uphold this assertion. Thus, the bank micro loans influence total microeconomic, supply, investment, total output and poverty reduction in Nigeria. (Drucker,1970 \& Anyanwu, 2004).

\section{Statement of Problem}

The key statement of problem that relating to this study are highlighted below:

1. Most financial institutions in Nigeria have not been able to provide micro credit to the unemployed youth in order to boost skills acquisition and increase in income generation in order to reduce poverty. Factors affecting performance of financial institutions according to profitability are broadly categorized into two; internal or micro and external or macro factors and all these affected financial institutions a lot.

2. Unavailability of empowerment scheme to reduce poverty in the country, is another challenge that the banking industry is facing in Nigeria.

3. Neglect of the informal market which are the market women, shoe cobblers, tie and die makers, roadside food sellers and motor mechanics and so on. Most financial institutions have not included these into their programme.

\section{Objectives of The Study}

1. Examine if financial institutions in Nigeria can provide micro credit to the unemployed populace in order to generate more income in their business activities and reduce poverty.

2. Determine if empowerment scheme in Nigeria can lead to skills acqusition and reduce poverty.

\section{Hypotheses of The Study}

$\mathrm{H}_{01}$ no significant relationship between micro credit provided by the financial institutions and highincome generation in order to reduce poverty among the unemployed populace in Nigeria.

$\mathrm{H}_{02}$ There is no relationship between empowerment scheme and skills acquistion among the youth in order to reduce poverty in Nigeria.

\section{Literature Review}

Micro loans are very crucial to economic development and poverty reduction in Nigeria these days. The global financial crisis has resulted in a worldwide slowdown of credit flow, and this affecting lending activity, (Adewole et al.,2018). The use of the term "strategic" has become increasingly common in the Nigeria business system. The use of the term, "strategic" has been associated with many aspects of business, although it is most commonly aligned with strategic planning. However, strategic planning is only a small part of an organization being strategic. Cardno, (2001) suggests that the Strategic Management concept encapsulates two wider areas of strategy and planning. Strategic management is different to other forms of management as it is characterized by complexity and ambiguity, espousing a vision for an organization to aspire their aim. Ashraf et al., (2014). The first aspect of strategic management is strategic planning. Strategic planning has a focus on the long-term macro-view of an organization, typically between 3-5 years and is made up of several strategic components that provide the framework on which strategy is built. There is also a focus on a proactive stance rather than being reactive (Bjialahi \&wei, (2011) and Yahaya et al., (2011) The second aspect of strategic management is that of operational planning. The focus for operational planning is more refined, looking specifically at the short-term with a micro-view of the organization. Operational planning is an important step in the implementation of strategy in an organization is also the 
process by which the wider staff of an organization can demonstrate and articulate how they intend to be involved in the strategy Both the strategic and operational plans should be reviewed annually (Ashraf,2014). The corporate strategy as the "set of businesses, markets or industries in which the organization competes and the distribution of resources among those businesses" (Bateman\& Snell, 2002). They further suggest that for each business there is a specific type of strategy, dependant on the nature of their business. For example, a company that continually produces the most expensive products in its industry would be referred to as having a high-end strategy. This can also be referred to as their strategic position. Ogundele, (2012) view poverty in any community is a serious setback to the economic development of the society. He explained further that Nigeria is a developing nation characterized by high rate of poverty, hunger and unemployment. Many people cannot cater for their needs due to this poverty. It seems as if all strategies applied in the past to fight poverty in Nigeria proved ineffective, the researchers of this study show that lending micro loans to entrepreneurs is a strategy for poverty reduction in Nigeria. The theories that most relevant to this study are; Classical, Evolution and Revolution theory. And it's in Schumpeter,1950 theory. This study also in line with previous study of Adewole et., al (2018). Who carried out research on Deposit Money Bank Credit and Economic Growth and poverty Reduction in Nigeria? The study uses of secondary data to obtain their finding. The study showed that there is positive relationship in Deposit money banks and poverty reduction in Nigeria.

\section{Methodology}

This research study adopted survey research method to examine reducing unemployment improve skills acquisition among youth, generate more income for them in order to reduce poverty by microfinance and commercial banks in Nigeria. Descriptive survey research design was adopted for this study, structured questionnaire was designed to obtain data from respondents on poverty alleviation, reduction of unemployment rate, boost skills acquisition and increase in income generation, through microcredit and empowerment scheme. The reason for the use of survey research method is that it enhances research data analysis and commonly used in similar research of this nature and it is of better adoption in Nigeria. The population of the study is financial institutions in Nigeria. 5 commercial and 5 micro finance banks were selected, using simple random sampling procedure. 10 staff were administered questionnaire in each bank, making 100. However, 80 questionnaires were properly returned and accounted for, while 20 were unreachable. The reliability test was piloted to ascertain whether the instrument was reliable. The result of the pilot study indicates a high level of instrument consistency: financial institutions' micro loans $($ Cronbach Alpha $=0.7)$ and reducing poverty $($ Cronbach Alpha $=0.77)$. Simple regression was used to test hypothesis to determine the degree of connections between the variables with the aid of Statistical Package for Social Science SPSS version 23.

\section{Results, Interpretation and Discussion}

There is significant relationship between micro loans and poverty reduction.

Model Summary

\begin{tabular}{|l|l|l|l|l|}
\hline Model & R & R Square & Adjusted R Square & Std. Error of the Estimate \\
\hline 1 & .194 & .0388 & .0145 & 1.18572 \\
\hline
\end{tabular}

Predictors: (Constant), financial institutions' micro loans. Dependent Variable: Poverty reduction. Source: authors 2019 compilation.

\begin{tabular}{|l|l|l|l|l|l|}
\hline Model & Sum of Square & Df & $\begin{array}{l}\text { Mean } \\
\text { Square }\end{array}$ & F & Sig. \\
\hline Regression & & 1 & 2.067 & & \\
\hline 1 & 2.094 & 1 & 1.508 & 32.667 & $.000^{\mathrm{b}}$ \\
\hline Total & 45.344 & 37 & & & \\
\hline
\end{tabular}

Dependent Variable: reducing Poverty.

Source: authors 2019 compilation. 
Table 2. Coefficients ${ }^{\mathrm{a}}$

\begin{tabular}{|l|l|l|l|l|}
\hline \multirow{2}{*}{ Model } & \multicolumn{2}{|l|}{$\begin{array}{l}\text { Unstandardized } \\
\text { Coefficients }\end{array}$} & \multicolumn{2}{l|}{ Standardized Coefficients } \\
\cline { 2 - 5 } & B & Std.Error & Beta & \\
\hline (Constant) Financial institutions & 3.138 & .525 & & 3.962 \\
$1 . \quad$ & .169 & .151 & .000 \\
\hline
\end{tabular}

a. Dependent Variable: reducing Poverty.

Source: authors 2019 compilation.

\section{Interpretation}

The output of the simple regression outcome as seen above shows that Financial Institutions' micro credit is statistically significant in predicting the dependent variable (reducing poverty). In a nutshell, given all the associated significant $p$-value to be less than $0.05>0.000$ for the dependent variable. The coefficient of determination $\left(\mathrm{R}^{2}=0.387\right)$ indicates that the predictor variable (reducing poverty) is responsible for $39 \%$ variation on the dependent variable. Consequently, the $61 \%$ remaining variations might be due to other factors not considered in this study. We can basically determine that Financial Institutions 'micro loans had a significant impact on skills acquisition, income generation and poverty alleviation in Nigeria. Likewise, the test of the overall model was found to be statistically significantly significant, given F-value of 32.677 and $\mathrm{p}=0.000$.

\section{Finding/Discussion}

This empirical study was directed in determination of the effect of financial institutions 'micro loans on reduction of poverty in Nigeria, while statistical test was applied to test hypothesis. Therefore, the statistical results at a significant level of 0.05 became clear that financial institutions 'micro loans have significant impact on skills acquisition, income generation and poverty alleviation in our dear country Nigeria. The discovery of this study is in line with the submissions of who affirm that poverty reduction and standard living can be improved with microcredit, empowerment scheme and skill acquisition. It is worthy to note that economic development strategy should be a vital component of Nigerian banking industry, and this we help economic growth.

\section{Conclusion}

Poverty has been identified as a debilitating cankerworm among human society, its effects are felt more in the developing countries. 2014 World Bank Report listed Nigeria third in the league of five countries with the largest number of the poor. Unemployment, lack of skills acquisition, poor income generation and inaccessibility of credit are among the factors that exacerbate poverty. Micro financing has been globally identified by development practitioners as an escape route from poverty. The Central Bank of Nigeria, in imbibing the microfinance catechism establish the microfinance framework in 2005 by which the existing community banks transformed into microfinance banks (CBN 2005). This study therefore set out to examine the impact of financial institutions 'micro loans as a means of reducing poverty: evidence from selected financial institutions in Osogbo. The study shows that availability of micro credits and loans to unemployed youth and populace; coupled with empowerment programmes will lead to skills acquisition, income generation which will in turn reduce poverty among Nigeria populace.

\section{Recommendation}

Core microfinance banks should be encouraged, presently the country has more of micro-deposit money banks masquerading as microfinance banks. The central banks through their restrictive monetary policy has left a number of commercial banks unable to grant loans that are enough to meet up with the required reduction of poverty and unemployment rate in Nigeria. Commercial banks, Microfinance banks and Development banks should inculcate economic development programmes that will enrich the general public financially. Microcredits should be given without long tedious process, high interest rate and collateral, this will not scare customers away from getting financial grants. The Nigerian banks should be less aggressive in their pursuit for profit, the promoters of the banking industry should be less capitalist and more socialists. 
They should also increase their expenditure on organizing seminars on training and empowerment schemes of graduates in the communities. Giving out loans should be gender sensitive, women, especially the rural women should be encouraged to embrace microfinance banking as a route to escape from poverty especially by this time that Nigeria is in economic recession.

\section{References}

1. Adewole, J.A., Akinmulegun, S.O., and Popoola, M.A. (2018). Deposit Money Bank Credit and Economic Growth and Poverty Reduction in Nigeria. International journal of Advance Research and Innovative Ideas in Education (IJARIIE).4(3),1711-1720.

2. Muogbo, U. S. (2013). The Impact of Strategic Management on Organisational Growth and Development A study of Selected Manufacturing Firms in Anambra state Nigeria. Journal of Business and Management, 7(1), 22-32.

3. Popoola, M. A. (2018). The Impact of Entrepreneurship Practice on Poverty Reduction in Nigeria: Evidence from Osun State, International Journal of Advance Research and Innovative Ideas in Education, 4(3), 762-767.

4. Raduan, J. H. (2009). The Impact of Strategic Management on Organization Growth and Development. Journal of Business and Management, 7(2),22-38.

5. Schumpeter, J. (950). Evolution and Revolution theory. Transnational Journal of Sciences and Technology, 1(2), 10-18.

6. Yahaya, K. A., Osemene, O. F., and Abdulraheem, A. (2011). Effectiveness of Microfinance Banks in Alleviating Poverty in Kwara State Nigeria. Global Journal of Management and Business Research, 11(4),10-22.

7. Anyanwu, C.M. (2004). Microfinance institutions in Nigeria: Policy, Practice and Potential in Nigeria. Central Bank of Nigeria. Research paper,1-31.

8. Anyakoha, E.U. (2006). Practical tips for Economic Empowerment and Survival.Nsuka Ap Express Road Nigeria.

9. Ashraf, M. A., and Ibrahim, Y. B. (2014). Poverty Alleviation and Identifying the Barriers to theRural Poor Participation in MFIs: A Case Study in Bangladesh. Journal of Economic Cooperation and Development,35(3), 99-132.

10. Baumol, W.J. (2012). Entrepreneurship Productive, Unproductive and Destructive. Journal of Business Venturing. 11(4), 64-71.

11. Baumol, W. V. (1986). Productivity, Growth, Convergence and Welfare.

12. Bequer, G. (2002). Small Business Entrepreneurship Development. Harlow Pearson Education limited.

13. Bjialali, P., \& Wei, X. (2011). Microfinance in China's Poor Area and Its Impact to Loan Type Evidence from Xinjiang Uygur Autonomous Region. 2011 Fourth International Conference on BusinessIntelligence and Financial Engineering, 486-490.

14. BSehrish, G., FaizaIr, S. and Khalid, Z. (2011). Factors Affecting bank Profitability in Pakistan. The Romanian Economic Journal, 6(3),55-62.

15. Central Bank of Nigeria (2005). Regulatory and Supervision framework for microfinance Banks in Nigeria.

16. Coulter, M.K. (2001). Entrepreneurship in Action. London Prentice Hall.Volume 2.

17. Ebiringa, T. (2012). Perspectives: Entrepreneurship Development and Growth of Enterprises in Nigeria. 2(2).

18. Ogundele, O. J. K. (2012). Entrepreneurship Training and Educational as a Strategic Tool for Poverty Alleviation in Nigeria. American International Journal of Contemporary Research, 2(1).

19. PAlmajali, Y. A., Alamro, S. H., \& Al-Soub, Y. Z. (2012). Factors Affecting the Financial Performance of Jordanian Insurance Companies Listed at Amman Stock Exchange, Journal of Management Research, 4(3).15-26.

20. Popoola, M.A. (2014). Effect of Bank consolidation on lending performance in Nigeria Banking system. Unpublished M.Sc. thesis at National Open University of Nigeria. 